\title{
Detailed parametrization of the pore space in tight clastic rocks from Poland based on laboratory measurement results
}

\author{
Paulina Krakowska ${ }^{1}$
}

Received: 6 May 2019 / Accepted: 13 July 2019 / Published online: 24 July 2019

(c) The Author(s) 2019

\begin{abstract}
Computed X-ray tomography (CT), together with nuclear magnetic resonance spectroscopy, pulse- and pressure-decay permeability methods, is a source of comprehensive information about the geometrical parameters of the pore space. Geological material consists of 31 samples of tight, gas-bearing, clastic rocks from different wells and formations. The purpose was to parametrize in detail the pore structure, revealing the relationships between the various parameters and estimating the equation for assessing the fluid flow ability of analyzed tight rocks. Following parameters were taken into consideration in the pore space characterization: thickness mean, equivalent diameter, anisotropy, elongation, sphericity, Feret diameter, Feret coefficient, Feret shape; shape factors: 2nd circularity coefficient, Malinowska coefficient and Danielsson coefficient; as well as parameters from 3D skeleton analysis: junctions, branches, coordination number. It was captured the dependence of logarithmic $T 2$ mean from NMR on junction count from CT, as well as $T 2$ cutoff from NMR on elongation from CT for the all samples. Logarithm of absolute permeability was estimated based on multiple linear regression analysis using only geometrical parameters from X-ray nanotomography, which is a benefit in the times of coring material decrease.
\end{abstract}

Keywords X-ray nanotomography $\cdot$ Tight rocks $\cdot$ Pore space $\cdot$ Permeability $\cdot$ Laboratory measurements $\cdot$ Petrophysics

\section{Introduction}

Detailed parametrization of the pore space in tight, gasbearing, clastic rocks is a key in understanding the porosity distribution and processes of the fluid flow through the pore space, especially important in hydrocarbons exploration (Karpyn et al. 2009; Zhang et al. 2017; Ghanizadeh et al. 2017; Krakowska 2017; Liu et al. 2018). The paper presents the combination of various laboratory measurement results: computed X-ray tomography (nanoscale), nuclear magnetic resonance spectroscopy and also pulse- and pressure-decay permeability method. Computed X-ray tomography (CT) is a well-known method in medicine and material engineering (Al-Raoush and Papadopoulos 2010; Kaczmarek et al. 2017). Physical bases of the method are connected with the X-ray absorption coefficient (Stock 2008). Pore space parametrization was based on the computed X-ray tomography

Paulina Krakowska

krakow@agh.edu.pl

1 Faculty of Geology, Geophysics and Environmental Protection, AGH University of Science and Technology, Al. Mickiewicza 30, Krakow, Poland and brought many useful information regarding the pore volume, pore shape and size, as well as the skeleton analysis. Geometrical parameters from CT correspond to the NMR results in the form of $T 2$ relaxation time parameters. The ability of fluid flow through the tight pore space is strongly controlled by the pore sizes, shapes and distributions. However, the absolute permeability can be estimated based only on the geometrical parameters of the pores and microcracks using advanced statistical tools as multiple linear regression analysis.

Computed X-ray tomography has an unquestionable advantage because it does not destroy the material and shows the selected objects, pores or minerals, in the 3D aspect (Wellington and Vinegar 1987; Kayser et al. 2006; Jarzyna et al. 2016; Krakowska et al. 2016; Puskarczyk et al. 2018). Still, it is many to research regarding the tight, gas-bearing formations, which are the object of the interest of petroleum industry (Josh et al. 2012; Guo et al. 2015; Verri et al. 2017). Hence, computed X-ray nanotomography is a valuable laboratory method for the qualitative and quantitative analysis of complicated pore structures and permeability estimation (Cnudde and Boone 2013; Mostaghimi et al. 2013; Krakowska and Puskarczyk 2015; Sun et al. 2017). 


\section{Materials and methods}

Research material consisted of Paleozoic 20 tight sandstone and 11 mudstone samples, from deep wells located in Poland. Sandstones come from Peri-Baltic syneclise, Pomeranian anticlinorium, Holy Cross anticlinorium and Lublin synclinorium, while mudstones Peri-Baltic syneclise and Lublin synclinorium.

Several laboratory methods were carried out on core samples: computed X-ray tomography (CT) in the form of $\mathrm{X}$-ray nanotomography, nuclear magnetic resonance spectroscopy (NMR), as well as pulse- and pressure-decay permeability method (PDP). CT provides 2D and 3D images of material for qualitative and quantitative analysis of selected objects: minerals or pores (Ketcham and Carlson 2001; Caubit et al. 2009; Cnudde et al. 2011). Highly specialized algorithms are necessary to obtain the proper visualization and quantitative information from objects. Firstly, CT data were processed (Feldkamp et al. 1984; Jędrychowski et al. 2017) and next analyzed in newly developed software poROSE (Habrat et al. 2017; Krakowska et al. 2018), in which many geometrical parameters were implemented for the proper 3D analysis of porous materials. poROSE software contains algorithms, which allow to parametrize the selected objects, e.g., pores, microcracks or minerals, and were built upon basis of the knowledge from different disciplines, as material engineering, medicine, petroleum geology and petrophysics (Madejski et al. 2018).

The following morphological parameters were taken into consideration in pore space characterization: thickness mean, equivalent diameter, anisotropy, elongation, sphericity, Feret diameter, Feret coefficient (determines the ratio of the maximum diameter of the object measured in two perpendicular directions), Feret shape (the ratio of the maximum length of the Feret diameter measured in the direction perpendicular to the line defined by the shortest Feret diameter to the length of the shortest Feret diameter), shape factors: 2nd circularity coefficient (determines the diameter of the circle with a perimeter length equal to the length of the perimeter of the tested object), Malinowska coefficient (combination of objects perimeter and surface area) and Danielsson coefficient (combination of object surface area and minimum distance to the object contour); from the skeleton analysis: junctions, isolated objects, branches, end branches, coordination number; as well as the result of spherical and ellipsoidal pore analysis. Calculations referred to the objects: pores and microfractures. Nuclear magnetic resonance spectroscopy (NMR) was carried out on saturated samples and processed using individual $T 2$ cutoffs. Moreover, pulse- and pressure-decay permeability methods were conducted for proper absolute permeability estimation (Handwerger et al. 2011). Detailed description of tools is presented in Table 1. The goal of the analysis was also to combine parameters from the CT and NMR, PDP, so an effort was made to search for the relationships between the different parameters.

Table 2 consists of the quantitative geometrical parameters of pores and microcracks in the form of median value calculated in the each samples (Feret diameter, sphericity, Feret shape, Feret coefficient) as well as total porosity values and grain size class. Although the samples come from different geological formations and wells (Table 2), they have a common feature in the form of low porosity $(0.02-4.42 \%)$ and maximum Feret diameter. Pores are characterized with the significant deviation from the shape of the ball, more elongated and edgy.

\section{Results and discussion}

All 31 samples were analyzed qualitatively and quantitatively. Exemplary visualization of the Cambrian tight sandstone is presented in Fig. 1, while Silurian mudstone sample is in Fig. 2.

Pore size distribution for exemplary samples of sandstone and mudstone is illustrated in Figs. 3 and 4 in the form of equivalent diameter and thickness mean parameters. Tight

Table 1 Laboratory tools description

\begin{tabular}{|c|c|c|}
\hline X-ray nanotomography $(\mathrm{CT})$ & $\begin{array}{l}\text { Nuclear magnetic resonance spectroscopy } \\
\text { (NMR) }\end{array}$ & $\begin{array}{l}\text { Pulse-decay/pressure-decay methods for abso- } \\
\text { lute permeability (PDP) }\end{array}$ \\
\hline $\begin{array}{l}\text { Nanotom } S \text { (general electric), X-ray tube: } \\
57-W \text {, voltage } 180 \mathrm{kV} \text { in maximum, } \\
\text { detector: Ham C } 7942 \mathrm{CA}-02 \text {, voxel size: } \\
0.5 \times 0.5 \times 0.5 \mu \mathrm{m}\end{array}$ & $\begin{array}{l}\text { NMR Maran } 23 \mathrm{MHz} \text { (oxford resonance } \\
\text { instruments, 2004), field of } 0.56 \mathrm{~T} \text {, tempera- } \\
\text { ture } 35^{\circ} \mathrm{C}\end{array}$ & $\begin{array}{l}\text { Pressure-decay: crushed material, "as received" } \\
\text { conditions, helium gas, no net overburden } \\
\text { stress; pulse-decay: core plug, net effective } \\
\text { stress: } 500,1500,3000,5000 \text { psi, nitrogen gas }\end{array}$ \\
\hline $\begin{array}{l}\text { Laboratory of Micro and Nano Tomography, } \\
\text { Faculty of Physics and Applied Computer } \\
\text { Science, AGH UST (Krakow, Poland) }\end{array}$ & $\begin{array}{l}\text { Laboratory of Petrophysics, Department of } \\
\text { Geophysics, Faculty of Geology, Geophysics } \\
\text { and Environmental Protection, AGH UST } \\
\text { (Krakow, Poland) }\end{array}$ & $\begin{array}{l}\text { TerraTek-Schlumberger Reservoir Laboratory } \\
\text { (Salt Lake City, USA) }\end{array}$ \\
\hline
\end{tabular}


Table 2 Research material characteristic. Values of Feret diameter, sphericity, Feret shape, Feret coefficient calculated for pores and microcracks are presented in the form of median value for the sample

\begin{tabular}{|c|c|c|c|c|c|c|c|c|}
\hline Sample number & GU & LS & $\begin{array}{l}\text { Grain size } \\
\text { (Wentworth } \\
\text { class) }\end{array}$ & $\begin{array}{l}\text { Total } \\
\text { porosity } \\
\text { CT }\end{array}$ & Feret diameter & Sphericity & Feret shape & Feret coefficient \\
\hline Unit & - & - & - & $(\%)$ & $(\mu \mathrm{m})$ & Unitless & Unitless & Unitless \\
\hline 1 & Lublin synclinorium & $\mathrm{Cm} 1$, ss & Fine sand & 3.24 & 8.38 & 0.49 & 1.80 & 1.00 \\
\hline 2 & Lublin synclinorium & $\mathrm{Cm} 1$, ss & Fine sand & 3.38 & 8.79 & 0.48 & 1.84 & 1.00 \\
\hline 3 & Peri-Baltic syneclise & $\mathrm{Cm} 2$, ss & Fine sand & 2.79 & 10.83 & 0.45 & 1.96 & 1.00 \\
\hline 4 & Peri-Baltic syneclise & $\mathrm{Cm} 2$, ss & Fine sand & 1.79 & 9.14 & 0.48 & 1.91 & 1.00 \\
\hline 5 & Lublin synclinorium & $\mathrm{O} 1, \mathrm{ss}$ & Very fine sand & 4.21 & 8.67 & 0.49 & 1.82 & 1.00 \\
\hline 6 & Lublin synclinorium & $\mathrm{O} 1, \mathrm{ss}$ & Very fine sand & 4.05 & 9.01 & 0.49 & 1.82 & 1.00 \\
\hline 7 & Peri-Baltic syneclise & $\mathrm{Cm} 1$, ss & Medium sand & 0.18 & 3.42 & 0.60 & 1.60 & 1.00 \\
\hline 8 & Peri-Baltic syneclise & $\mathrm{Cm} 1, \mathrm{ss}$ & Medium sand & 0.04 & 3.42 & 0.65 & 1.50 & 1.00 \\
\hline 9 & Lublin synclinorium & $\mathrm{D} 2, \mathrm{ss}$ & Fine sand & 0.05 & 3.77 & 0.59 & 1.61 & 1.00 \\
\hline 10 & Lublin synclinorium & $\mathrm{D} 2, \mathrm{ss}$ & Fine sand & 0.06 & 3.81 & 0.58 & 1.60 & 1.00 \\
\hline 11 & Pomeranian antyclinorium & $\mathrm{C}, \mathrm{ss}$ & No data & 0.36 & 4.03 & 0.58 & 1.62 & 1.00 \\
\hline 12 & Pomeranian antyclinorium & $\mathrm{C}$, ss & No data & 0.19 & 4.10 & 0.58 & 1.61 & 1.00 \\
\hline 13 & Holy Cross antyclinorium & $\mathrm{C} 1, \mathrm{ss}$ & No data & 0.15 & 3.85 & 0.53 & 1.70 & 1.00 \\
\hline 14 & Holy Cross antyclinorium & $\mathrm{C} 1$, ss & No data & 0.08 & 4.15 & 0.54 & 1.67 & 1.00 \\
\hline 15 & Peri-Baltic syneclise & $\mathrm{Cm}$, ss & Very fine sand & 0.04 & 3.42 & 0.59 & 1.54 & 1.15 \\
\hline 16 & Peri-Baltic syneclise & $\mathrm{Cm}$, ss & Very fine sand & 0.02 & 4.15 & 0.62 & 1.55 & 1.18 \\
\hline 17 & Peri-Baltic syneclise & $\mathrm{Cm}$, ss & Very fine sand & 3.59 & 10.43 & 0.40 & 2.06 & 1.08 \\
\hline 18 & Peri-Baltic syneclise & $\mathrm{Cm}$, ss & Very fine sand & 4.42 & 9.32 & 0.42 & 2.05 & 1.10 \\
\hline 19 & Peri-Baltic syneclise & $\mathrm{Cm}$, ss & Very fine sand & 0.65 & 8.80 & 0.47 & 1.92 & 1.33 \\
\hline 20 & Peri-Baltic syneclise & $\mathrm{Cm}$, ss & Very fine sand & 1.91 & 8.81 & 0.45 & 1.99 & 1.36 \\
\hline 21 & Lublin synclinorium & $\mathrm{S} 3$, mds & Fine silt & 1.92 & 7.15 & 0.52 & 1.74 & 1.00 \\
\hline 22 & Lublin synclinorium & S3, mds & Fine silt & 0.18 & 4.53 & 0.55 & 1.67 & 1.25 \\
\hline 23 & Lublin synclinorium & S3, mds & Fine silt & 1.75 & 6.58 & 0.50 & 1.79 & 1.25 \\
\hline 24 & Lublin synclinorium & S3, mds & Fine silt & 0.12 & 5.46 & 0.53 & 1.68 & 1.20 \\
\hline 25 & Lublin synclinorium & S3, mds & Fine silt & 1.05 & 6.83 & 0.52 & 1.76 & 1.23 \\
\hline 26 & Lublin synclinorium & S3, mds & Fine silt & 1.76 & 7.70 & 0.50 & 1.79 & 1.15 \\
\hline 27 & Lublin synclinorium & S3, mds & Fine silt & 1.00 & 5.54 & 0.55 & 1.69 & 1.20 \\
\hline 28 & Peri-Baltic syneclise & $\mathrm{S} 2$, mds & Coarse silt & 0.07 & 3.85 & 0.61 & 1.57 & 1.00 \\
\hline 29 & Peri-Baltic syneclise & $\mathrm{S} 2$, mds & Coarse silt & 0.13 & 3.81 & 0.59 & 1.61 & 1.00 \\
\hline 30 & Peri-Baltic syneclise & $\mathrm{S} 1$, mds & Fine silt & 2.17 & 8.80 & 0.46 & 2.09 & 1.47 \\
\hline 31 & Peri-Baltic syneclise & $\mathrm{S} 1$, mds & Fine silt & 2.76 & 9.00 & 0.46 & 2.09 & 1.50 \\
\hline
\end{tabular}

Symbols $G U$-geological unit in Poland, $L S$-lithostratigraphy, $\mathrm{Cm}$-Cambrian, $\mathrm{Cm} 1$-lower Cambrian, $\mathrm{Cm} 2$-middle Cambrian, $\mathrm{O} 1$-lower Ordovician, $S 1$ - lower Silurian, $S 2$-middle Silurian, $S 3$ - upper Silurian, $D 2$-middle Devonian, $C$ - carboniferous, $C 1$-lower carboniferous, $s s$ - sandstone, $m d s$ - mudstone

sandstones consist of pores within large range of diameters in comparison with mudstones. Most of the pore diameters are below $10 \mu \mathrm{m}$ in the mudstone group, while in the sandstones below $50 \mu \mathrm{m}$. Analysis provided information about the number of objects in each sample. It appeared that mudstones are represented by the larger group but with smaller diameters. It is worth paying attention that the sizes of compared samples (Figs. 3 and 4) were different. Sample 17 (Fig. 3) has a voxel size $700 \times 700 \times 2000$, while sample 26 (Fig. 4) $-500 \times 500 \times 1880$.
Shape factors give an insight into the pore shape, which influences the filtration abilities. Danielsson coefficient is very sensitive for the pore shape (low values for the elongated objects), while Malinowska coefficient is more likely sensitive for the pyramid shape. Slight variability with the size and the rotation shows Danielsson coefficient, while Malinowska coefficient is stable. Shape factors were implemented and calculated using adopted 3D algorithms. Figures 5 and 6 show the Danielsson coefficient in the sandstone and mudstone group, for each sample, in the form of median and quartile values. Pores in tight sandstones have more 


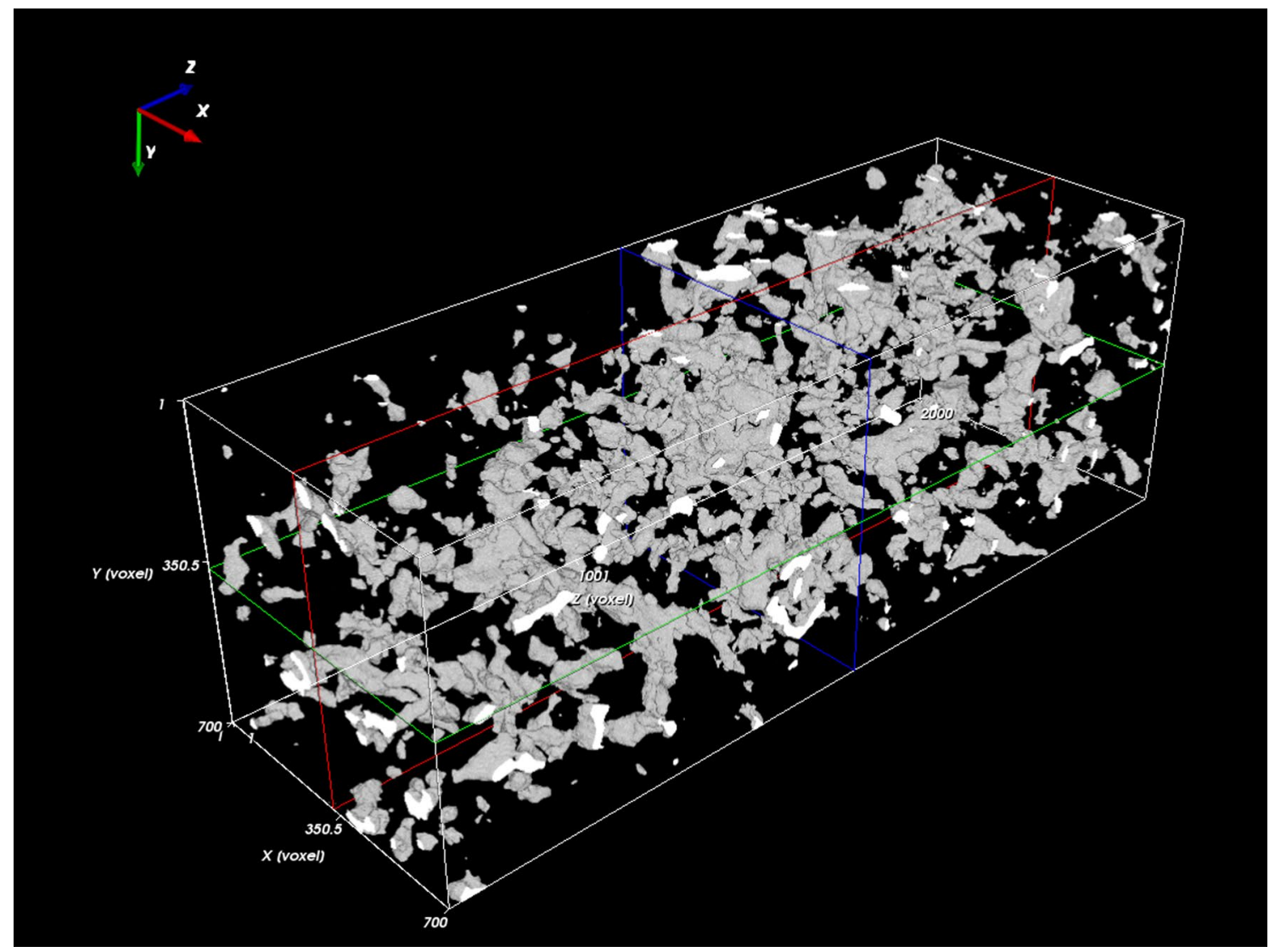

Fig. 1 3D image of the tight sandstone pore space (core sample from Cambrian, sample 17), image size: $700 \times 700 \times 2000$ voxels $\left(350 \times 350 \times 1000 \mu \mathrm{m}^{3}\right)$, poROSE software

complicated shapes and differed within the group. Mudstone pores are more similar in shape. Samples 30 and 31 were probed from the wells in the Peri-Baltic syneclise, while the rest of the samples-from the Lublin synclinorium, hence the difference in the Danielsson coefficient.

Shape factors were combined together with the NMR results. Several data sets were prepared with the different statistics calculated for each parameter in each sample, as median, percentile, quartile, for all detected objects in the sample (pores and microcracks). Malinowska coefficient correlates with $T 2$ cutoff 1 for clay bound water and capillary bound water $(R=0.61), T 2$ cutoff 2 for bulk water irreducible and moveable fluid volume $(R=0.63)$ for the 10 percentile values, as well as with $T 2$ cutoff 2 for bulk water irreducible and moveable fluid volume $(R=0.60)$ for the median values. Second circularity coefficient $(R=0.61)$ and Danielsson coefficient $(R=0.61)$ built the relationships with $T 2$ cutoff 2 for bulk water irreducible and moveable fluid volume for the 10 percentile value data set.

Moreover, spherical and ellipsoidal pore shape analysis was carried out regarding the pore shape. Spherical pores parameter describes number of spherical pores per unit of rock volume (unit $1 / \mathrm{m}^{3}$ or $1 /$ voxels). Average parameter of spherical pores in sandstone group is lower than in mudstones and is equal to $1.78 \mathrm{E}-7$ and $5.84 \mathrm{E}-7$, respectively. It means that more spherical pores are detected in mudstones than in sandstones, in the rock volume. In comparison, sandstone samples 5 and 6 have about 300 spherical pores, while samples 15 and 16 less are than 35 . Mudstone samples are characterized by higher number of spherical pores in comparison with sandstone samples, which is around 300 spherical pores. Average diameter of spherical pores is quite similar, more or less about $1.05 \mu \mathrm{m}$ for sandstones, with $0.24 \mu \mathrm{m}$ of standard deviation, while for mudstones $0.96 \mu \mathrm{m}$ and $0.20 \mu \mathrm{m}$, respectively.

Ellipsoidal pores parameter is equal to $1.90 \mathrm{E}-6$ for sandstones and 4.91E -6 for mudstones and is higher in mudstones. It means that relatively there are more spherical and ellipsoidal pores in mudstones, but there is no information about the pore volume. Sandstone samples have in average about 1600 ellipsoidal pores, while mudstones-2700. Sample volumes were not the same, what influences the number of objects. Nevertheless, in general more objects were detected in mudstone samples. Pore shape factor is ratio of shorter radii of the axis to the longest, evaluated in each plane. Pore concentration factor is calculated by the 


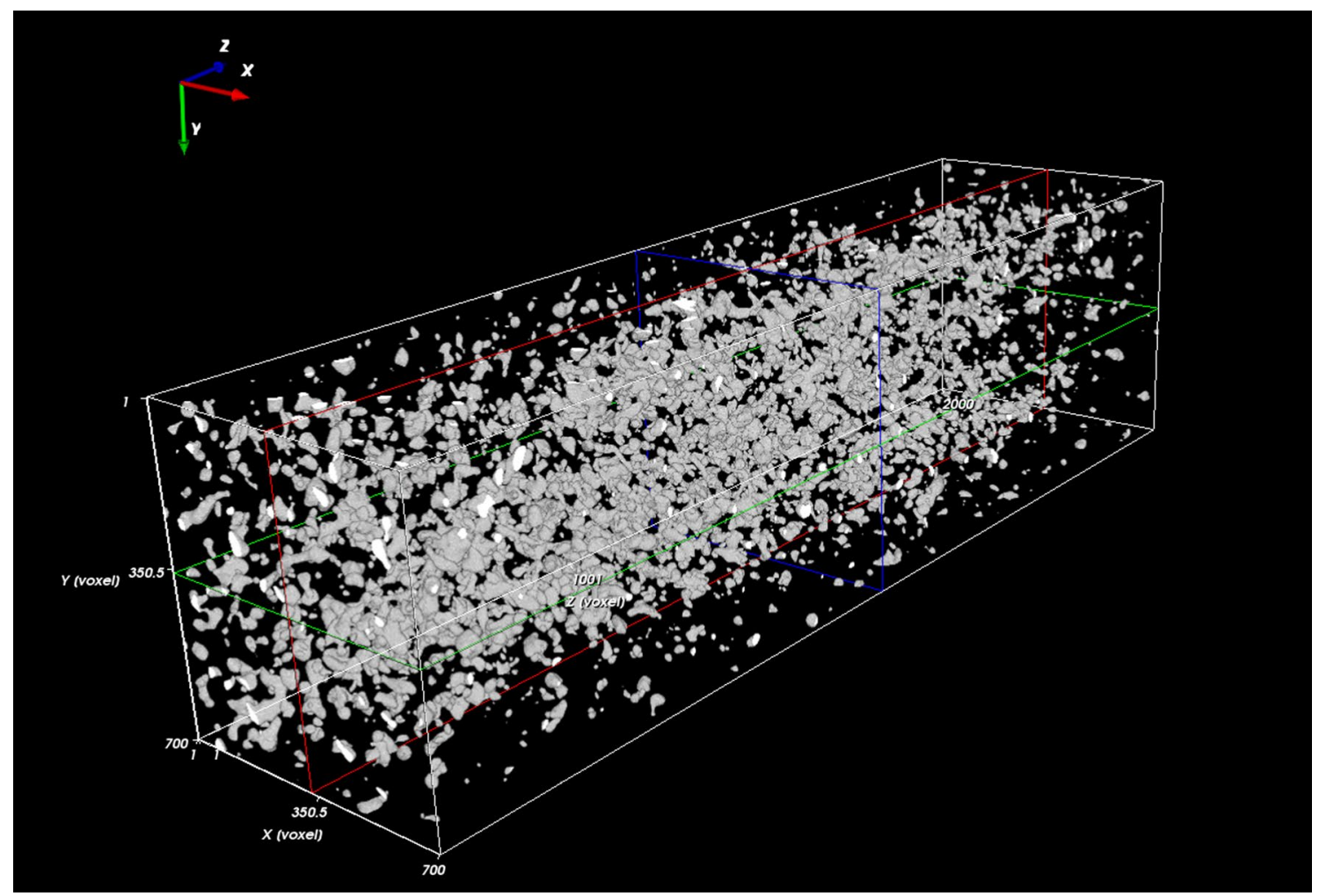

Fig. 2 3D image of the mudstone pore space (core sample from Silurian, sample 26), image size: $500 \times 500 \times 1880$ voxels $\left(250 \times 250 \times 940 \mu \mathrm{m}^{3}\right)$, poROSE software

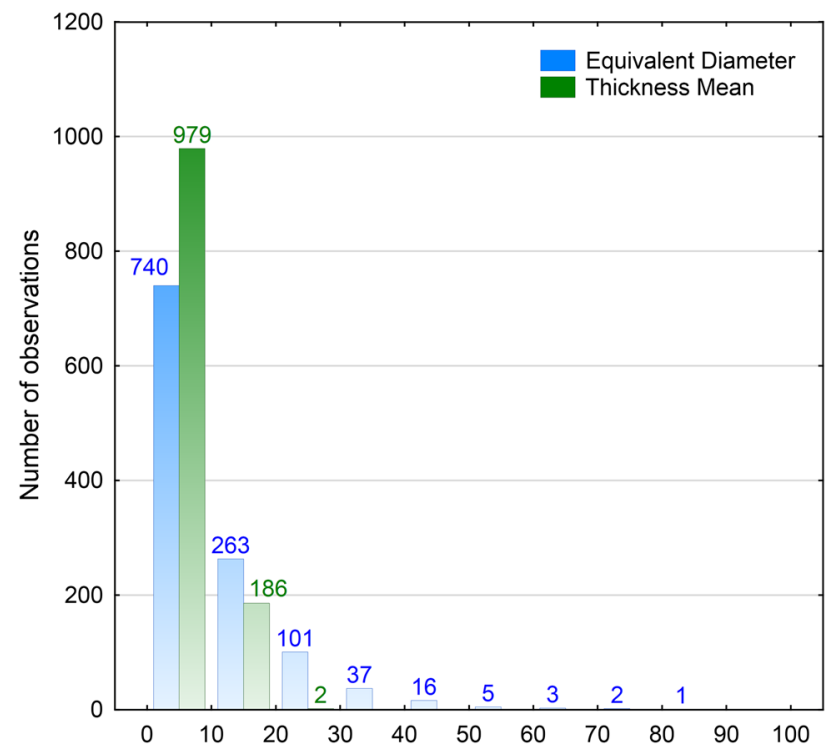

Fig. 3 Pore size distribution of exemplary tight sandstone sample 17 in the form of equivalent diameter and thickness mean in micrometers

product of the number of pores per unit of rock volume and the length of the longer half-axis of the ellipsoid. Pore shape factor is around 0.52 and pore concentration factor around

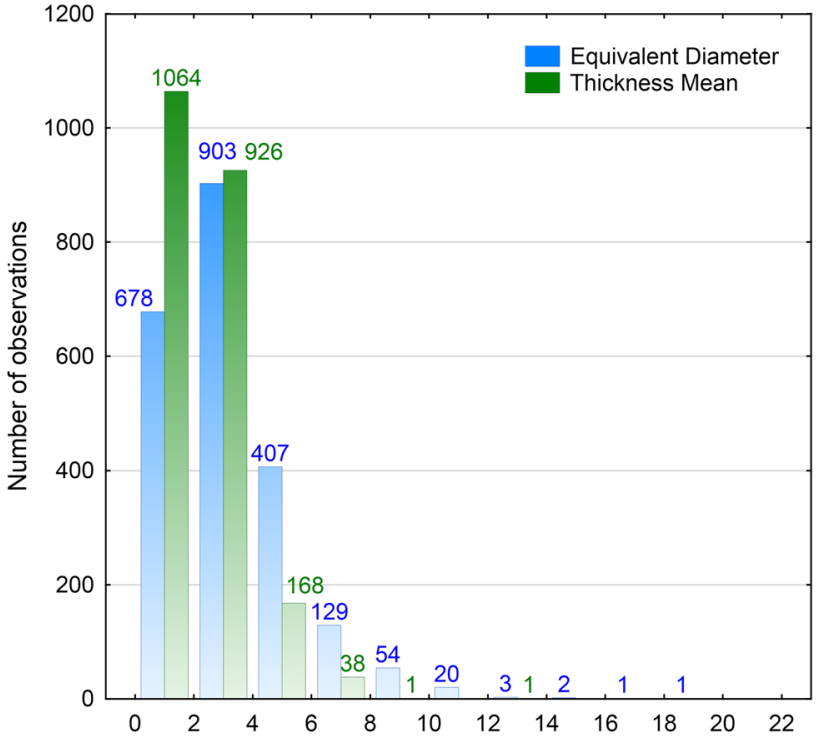

Fig. 4 Pore size distribution of exemplary mudstone sample 26 in the form of equivalent diameter and thickness mean in micrometers

6.1 for mudstones and 0.48 and 2.38 for sandstones, respectively. Moreover, pore concentration factor is very diverse, which means that samples differ with the longer half-axis. 
Fig. 5 Danielsson coefficient for the tight sandstone samples

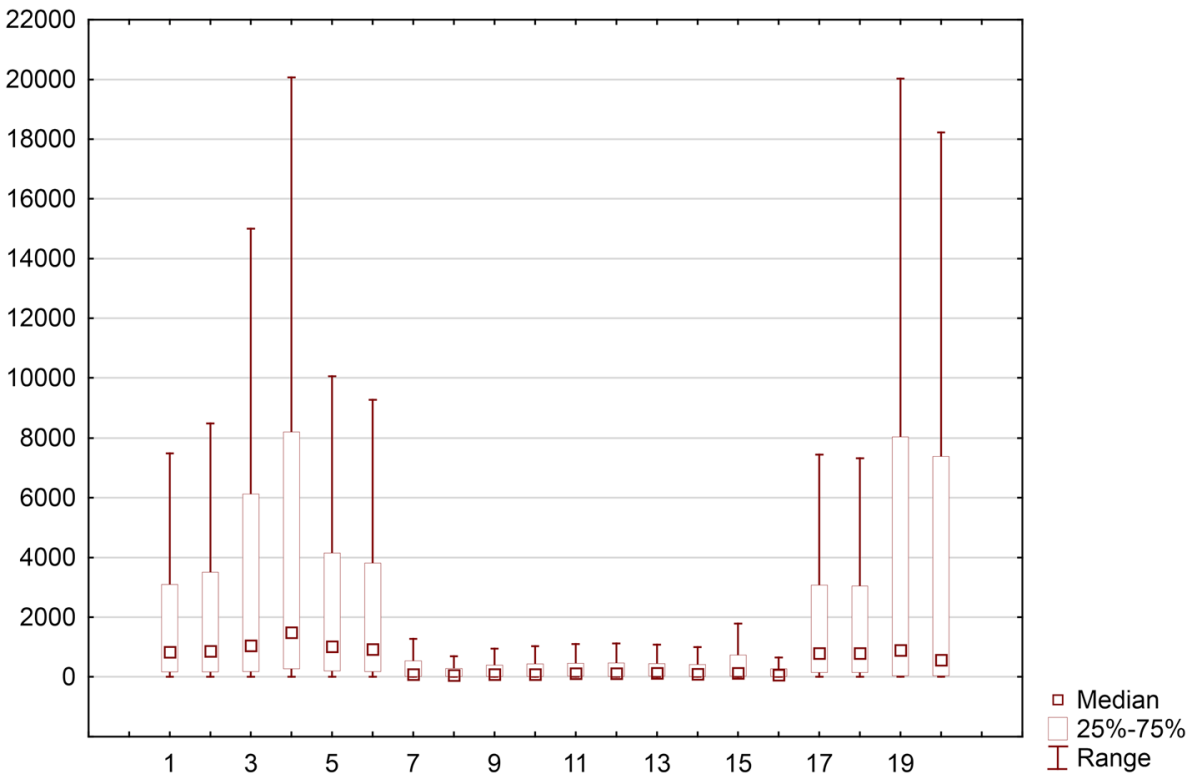

Fig. 6 Danielsson coefficient for the mudstone samples

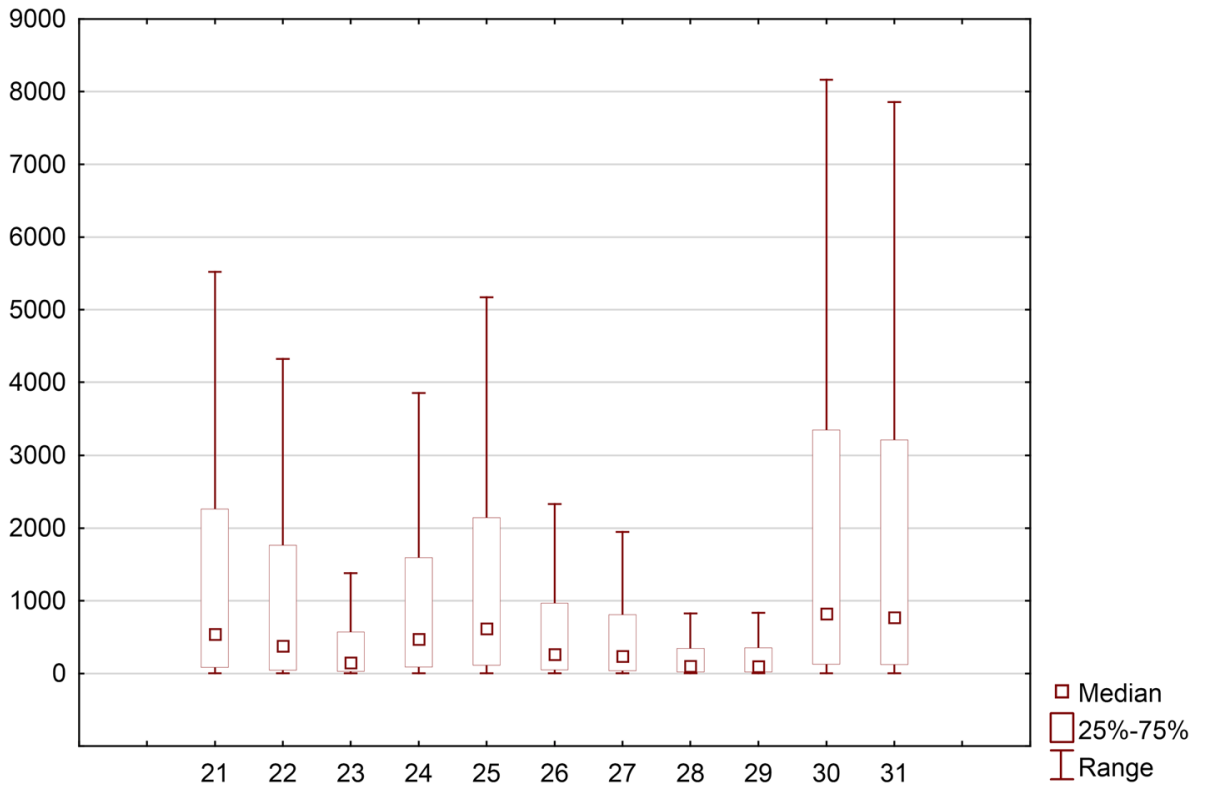

3D skeleton analysis includes information about junctions (Junctions Pxs Count; pixels that intersect on at least two branches), isolated objects (Isolated Pxs Count), ends of branches (End Pxs Count), branches (pixels that create run and end with junction). It provided unique information about the pore space connections and complexity. Results of 3D skeleton analysis in the form of junction and branch visualization are presented in Figs. 7 and 8. Detailed quantitative results are illustrated in Table 3.

Detailed skeleton analysis provided information about the average coordination number (Ridgway \& Tarbuck 1967). Average coordination number in many cases was a negative number. That is example of poorly developed pore space.
Only 2 from 11 samples from the mudstones group had a positive value and only 10 from 20 samples in sandstone group, what indicated that sandstones are characterized by more complex structure. Number of junctions varied from 6 to about 31,686 , for arithmetic average 3701 in sandstones, while in mudstones from 31 to 2210 , with average 668 . It means that sandstones are characterized by pores with complicated shapes, so after transformation into skeleton resulted in higher number of Junctions. However, the number of junctions and branches is not very high, as for conventional rocks.

Different definition of coordination number is connected with the number or branches which are connected with the 


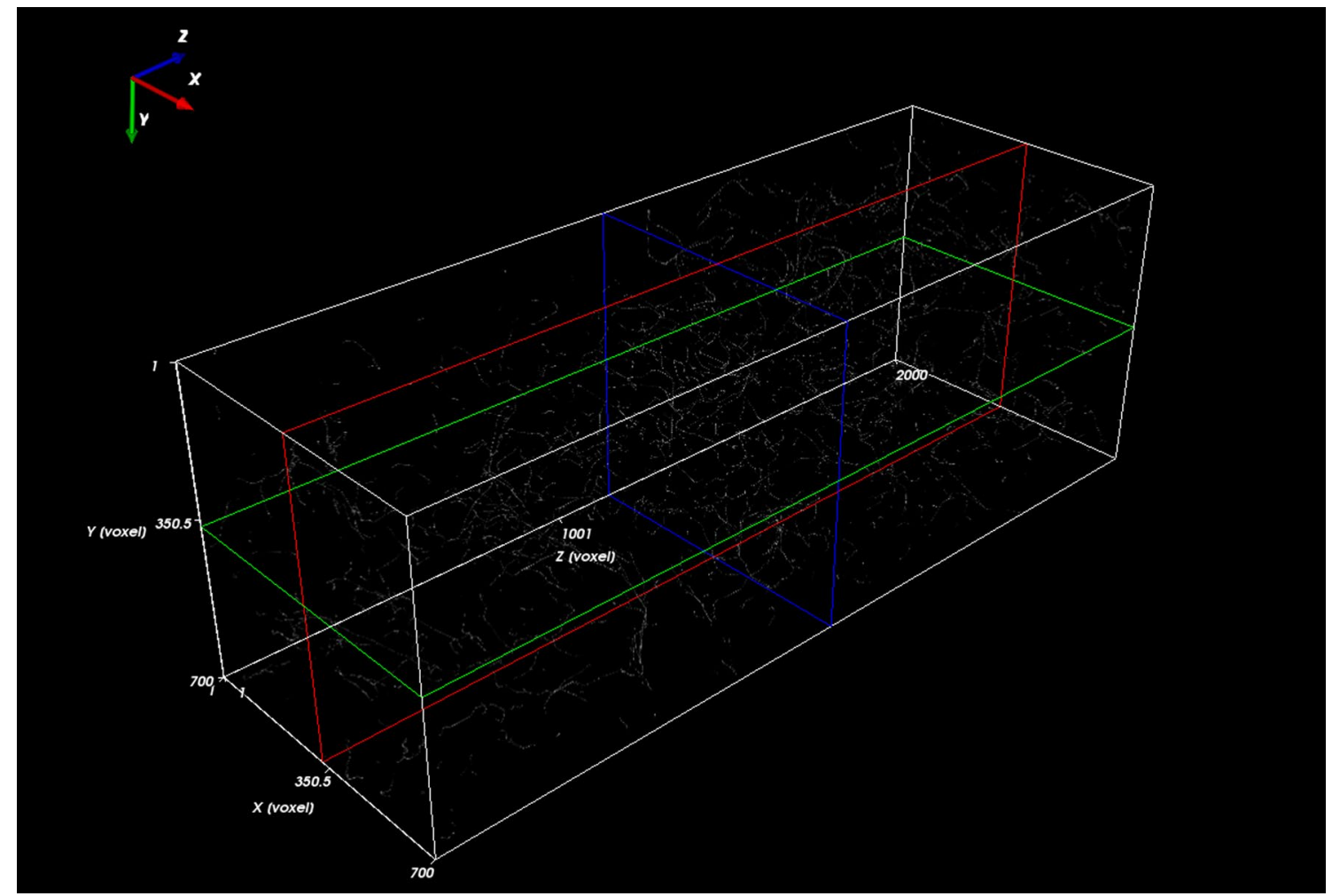

Fig. 7 Image of the skeleton analysis for the Cambrian tight sandstone sample 17

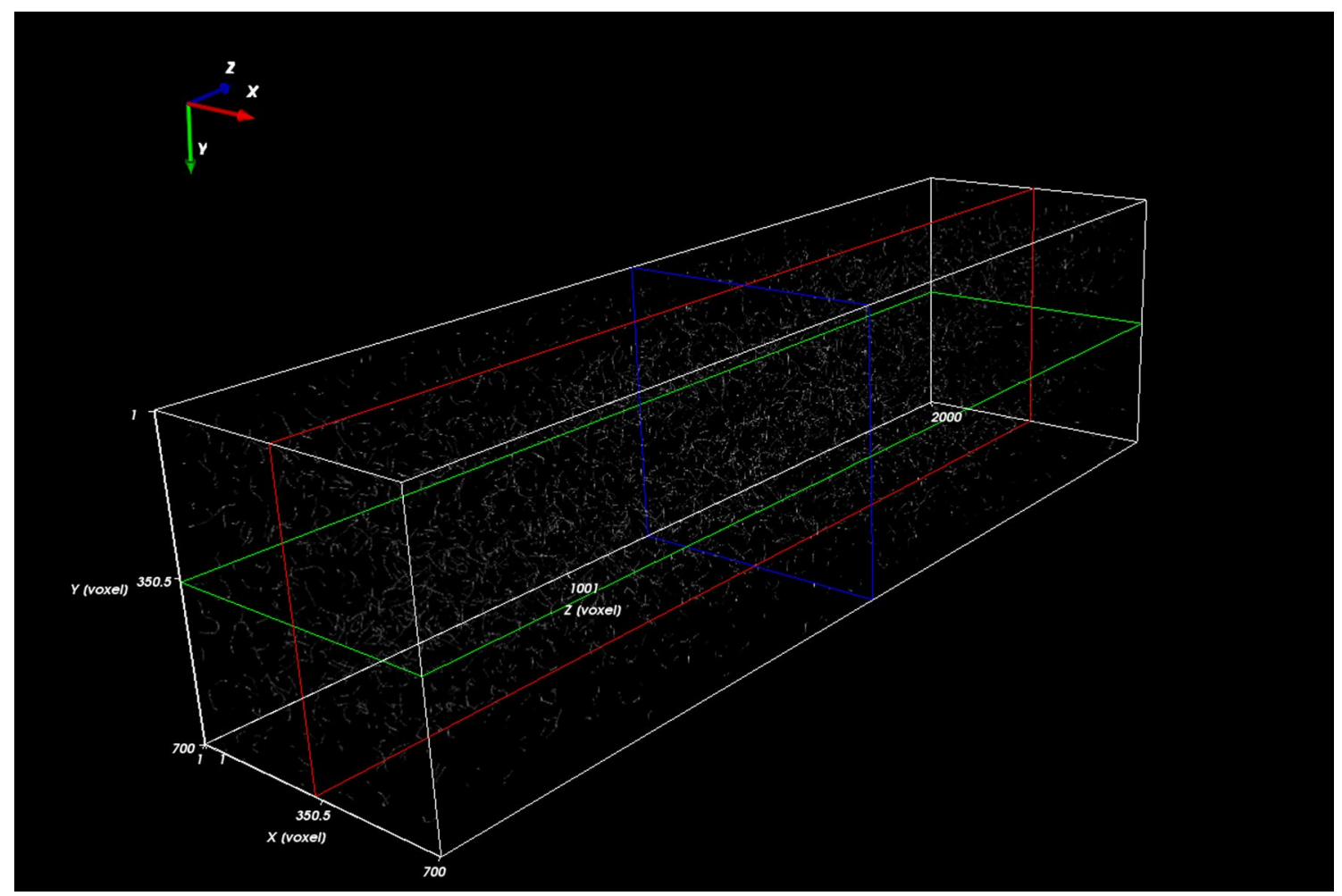

Fig. 8 Image of the skeleton analysis for the Silurian mudstone sample 26 
Table 3 Results of basic skeleton analysis for each sample. Symbols as in Table 2

\begin{tabular}{|c|c|c|c|c|c|c|}
\hline Sample & LS & $\begin{array}{l}\text { Junctions } \\
\text { Pxs count }\end{array}$ & $\begin{array}{l}\text { Isolated } \\
\text { Pxs count }\end{array}$ & End Pxs count & Branches count & $\begin{array}{l}\text { Average coordi- } \\
\text { nation number }\end{array}$ \\
\hline 1 & $\mathrm{Cm} 1, \mathrm{ss}$ & 5334 & 875 & 9789 & 7829 & 1.10 \\
\hline 2 & $\mathrm{Cm} 1$, ss & 5515 & 864 & 9906 & 8019 & 1.11 \\
\hline 3 & $\mathrm{Cm} 2, \mathrm{ss}$ & 5393 & 192 & 4187 & 4864 & 1.02 \\
\hline 4 & $\mathrm{Cm} 2, \mathrm{ss}$ & 2438 & 191 & 3055 & 3043 & 1.24 \\
\hline 5 & $\mathrm{O} 1, \mathrm{ss}$ & 31,686 & 555 & 7792 & 7472 & 0.22 \\
\hline 6 & $\mathrm{O} 1, \mathrm{ss}$ & 13,684 & 543 & 7679 & 7212 & 0.49 \\
\hline 7 & $\mathrm{Cm} 1$, ss & 196 & 204 & 836 & 352 & -0.67 \\
\hline 8 & $\mathrm{Cm} 1, \mathrm{ss}$ & 12 & 127 & 486 & 100 & -23.83 \\
\hline 9 & D2, ss & 40 & 141 & 566 & 172 & -5.55 \\
\hline 10 & $\mathrm{D} 2, \mathrm{ss}$ & 37 & 223 & 955 & 244 & -12.62 \\
\hline 11 & $\mathrm{C}, \mathrm{ss}$ & 423 & 675 & 3628 & 1273 & -2.55 \\
\hline 12 & $\mathrm{C}$, ss & 268 & 560 & 2448 & 810 & -3.08 \\
\hline 13 & $\mathrm{C} 1, \mathrm{ss}$ & 301 & 391 & 2302 & 814 & -2.23 \\
\hline 14 & $\mathrm{C} 1$, ss & 107 & 258 & 1281 & 438 & -3.78 \\
\hline 15 & $\mathrm{Cm}$, ss & 59 & 63 & 275 & 115 & -0.76 \\
\hline 16 & $\mathrm{Cm}$, ss & 6 & 30 & 138 & 31 & -12.66 \\
\hline 17 & $\mathrm{Cm}$, ss & 3106 & 114 & 3625 & 3916 & 1.35 \\
\hline 18 & $\mathrm{Cm}$, ss & 3668 & 124 & 4129 & 4581 & 1.37 \\
\hline 19 & $\mathrm{Cm}$, ss & 374 & 105 & 1448 & 831 & 0.57 \\
\hline 20 & $\mathrm{Cm}$, ss & 1376 & 258 & 4006 & 2555 & 0.80 \\
\hline 21 & $\mathrm{~S} 3$, mds & 634 & 468 & 3944 & 1783 & -0.59 \\
\hline 22 & $\mathrm{~S} 3$, mds & 43 & 548 & 2772 & 694 & -32.18 \\
\hline 23 & S3, mds & 1262 & 761 & 6211 & 2999 & -0.16 \\
\hline 24 & S3, mds & 37 & 141 & 745 & 239 & -7.21 \\
\hline 25 & S3, mds & 376 & 610 & 4872 & 1854 & -3.09 \\
\hline 26 & S3, mds & 744 & 745 & 6329 & 2784 & -1.02 \\
\hline 27 & S3, mds & 57 & 336 & 1869 & 553 & -13.38 \\
\hline 28 & $\mathrm{~S} 2$, mds & 31 & 322 & 1321 & 327 & -21.51 \\
\hline 29 & $\mathrm{~S} 2$, mds & 101 & 605 & 2763 & 728 & -12.94 \\
\hline 30 & $\mathrm{~S} 1, \mathrm{mds}$ & 1862 & 542 & 8351 & 4537 & 0.38 \\
\hline 31 & $\mathrm{~S} 1, \mathrm{mds}$ & 2210 & 529 & 8414 & 4782 & 0.52 \\
\hline
\end{tabular}

single pore (Rabbani et al. 2016). Coordination number defines quality of pores connection. Maximum value of coordination number in sandstone group is 17 , while average is equal to about 3 (Table 4). Mudstones are characterized with maximum coordination number equal to 6 and average about 3 . It indicates that sandstones are more diverse in pores connection in comparison with mudstones but on average they are very similar. Almost all samples have low number of junctions, with the highest average for the Cambrian sandstone 7 and Silurian mudstone 30 .

Maximum coordination number in the sample (Max CN Sample) correlates with $T 2$ cutoff 2 for bulk water irreducible and moveable fluid volume $(R=0.63)$ and logarithmic $T 2$ mean T2ML $(R=0.63)$. There was no relationship detected for the coordination number and absolute permeability.

It is worth paying attention to the strong relationships between following parameters from different laboratory methods: logarithmic mean of transverse relaxation time from NMR and number of junctions from CT, logarithm of absolute permeability from PDP and anisotropy from CT, $T 2$ cutoff 2 from NMR (for bulk water irreducible and moveable fluid volume) and elongation from CT. Figures 9, 10 and 11 show the mentioned relationships. Parameters from X-ray nanotomography usually build the relationships with the NMR spectroscopy results in the form of $T 2$ relaxation time because it corresponds to the pore sizes. Mudstone samples in Fig. 9 concentrate in the range of low logarithmic $T 2$ mean (T2ML) from NMR and low Junctions Pxs Count from CT, revealing poorer development of the pore space. Figure 10 shows dependence of logarithm of absolute permeability from pulse- and pressure-decay method on anisotropy from CT. Sandstone samples are divided into two groups: group of low absolute permeability and high anisotropy values from CT and group of high absolute permeability and low 
Table 4 Coordination number $(\mathrm{CN})$ for all samples

\begin{tabular}{|c|c|c|c|c|c|c|c|c|}
\hline Sample & LS & $\begin{array}{l}\text { Max } \\
\text { junction } \\
\text { sample }\end{array}$ & $\begin{array}{l}\text { Ave. } \\
\text { junction } \\
\text { sample }\end{array}$ & $\begin{array}{l}\text { Std dev. } \\
\text { junction } \\
\text { sample }\end{array}$ & $\begin{array}{l}\text { Min } \\
\text { CN } \\
\text { sample }\end{array}$ & $\begin{array}{l}\text { Max } \\
\mathrm{CN} \\
\text { sample }\end{array}$ & Ave. CN sample & $\begin{array}{l}\text { Std dev. } \\
\text { CN sample }\end{array}$ \\
\hline 1 & $\mathrm{Cm} 1$, ss & 100 & 4 & 9 & 0 & 6 & 2.93 & 0.51 \\
\hline 2 & $\mathrm{Cm} 1$, ss & 86 & 4 & 8 & 1 & 6 & 2.93 & 0.52 \\
\hline 3 & $\mathrm{Cm} 2$, ss & 183 & 7 & 15 & 1 & 6 & 2.95 & 0.54 \\
\hline 4 & $\mathrm{Cm} 2$, ss & 70 & 5 & 9 & 1 & 5 & 2.94 & 0.53 \\
\hline 5 & $\mathrm{O} 1, \mathrm{ss}$ & 159 & 6 & 14 & 0 & 17 & 2.96 & 0.59 \\
\hline 6 & $\mathrm{O} 1$, ss & 197 & 6 & 15 & 1 & 7 & 2.95 & 0.53 \\
\hline 7 & $\mathrm{Cm} 1$, ss & 54 & 15 & 19 & 1 & 5 & 2.99 & 0.47 \\
\hline 8 & $\mathrm{Cm} 1$, ss & 3 & 2 & 1 & 1 & 3 & 2.50 & 0.76 \\
\hline 9 & $\mathrm{D} 2, \mathrm{ss}$ & 12 & 3 & 4 & 2 & 4 & 3.05 & 0.37 \\
\hline 10 & D2, ss & 6 & 2 & 2 & 2 & 5 & 3.06 & 0.73 \\
\hline 11 & $\mathrm{C}, \mathrm{ss}$ & 27 & 3 & 4 & 1 & 4 & 2.89 & 0.51 \\
\hline 12 & $\mathrm{C}$, ss & 60 & 4 & 9 & 1 & 6 & 2.92 & 0.65 \\
\hline 13 & $\mathrm{C} 1$, ss & 15 & 2 & 3 & 1 & 4 & 2.78 & 0.58 \\
\hline 14 & $\mathrm{C} 1$, ss & 7 & 2 & 2 & 1 & 4 & 2.80 & 0.63 \\
\hline 15 & $\mathrm{Cm}$, ss & 31 & 5 & 10 & 2 & 4 & 2.86 & 0.41 \\
\hline 16 & $\mathrm{Cm}$, ss & 2 & 1 & 0 & 2 & 3 & 2.75 & 0.43 \\
\hline 17 & $\mathrm{Cm}$, ss & 140 & 6 & 14 & 1 & 5 & 2.95 & 0.48 \\
\hline 18 & $\mathrm{Cm}$, ss & 546 & 7 & 33 & 0 & 6 & 2.96 & 0.49 \\
\hline 19 & $\mathrm{Cm}$, ss & 11 & 2 & 2 & 1 & 5 & 2.85 & 0.55 \\
\hline 20 & $\mathrm{Cm}$, ss & 26 & 3 & 4 & 1 & 5 & 2.89 & 0.58 \\
\hline 21 & $\mathrm{~S} 3$, mds & 10 & 2 & 1 & 0 & 5 & 2.76 & 0.60 \\
\hline 22 & $\mathrm{~S} 3$, mds & 2 & 1 & 0 & 1 & 3 & 2.40 & 0.71 \\
\hline 23 & $\mathrm{~S} 3$, mds & 129 & 2 & 8 & 0 & 4 & 2.83 & 0.52 \\
\hline 24 & S3, mds & 4 & 1 & 1 & 2 & 4 & 2.58 & 0.57 \\
\hline 25 & $\mathrm{~S} 3$, mds & 5 & 1 & 1 & 1 & 4 & 2.69 & 0.59 \\
\hline 26 & $\mathrm{~S} 3$, mds & 6 & 1 & 1 & 0 & 5 & 2.70 & 0.61 \\
\hline 27 & $\mathrm{~S} 3$, mds & 2 & 1 & 0 & 1 & 3 & 2.50 & 0.62 \\
\hline 28 & $\mathrm{~S} 2$, mds & 3 & 2 & 1 & 2 & 4 & 2.88 & 0.48 \\
\hline 29 & $\mathrm{~S} 2$, mds & 6 & 2 & 1 & 1 & 4 & 2.75 & 0.54 \\
\hline 30 & $\mathrm{~S} 1$, mds & 35 & 2 & 3 & 0 & 5 & 2.79 & 0.55 \\
\hline 31 & $\mathrm{~S} 1$, mds & 25 & 2 & 3 & 0 & 6 & 2.83 & 0.54 \\
\hline
\end{tabular}

Symbols Min - minimum value, Max — maximum value, Ave — average value, Std Dev—standard deviation value, other symbols as in Table 2 anisotropy values. Mudstone samples cover almost all range of anisotropy values and lower values of absolute permeability. Dependence of $T 2$ cutoff 2 (for bulk water irreducible and moveable fluid volume) from NMR on elongation from CT is presented in Fig. 11. Two groups of sandstone samples are visible: group of higher elongation values from CT and lower $T 2$ cutoff 2 and group of lower elongation values and higher $T 2$ cutoff 2 . Mudstone samples are characterized by the higher elongation values, except two samples, which have more pores with sphere shape.

Multiple linear regression method (MLR) was applied to search for the best equation for the absolute permeability estimation using only X-ray nanotomography results (TIBCO 2017). Analysis was conducted in Statistica 12. The purpose is to establish the formula for minimizing the core destruction, as a very valuable material. MLR was done for the all clastic samples taking into consideration the one dependent parameter-logarithm of absolute permeability from pulse- and pressure-decay permeability method and independent variables as all available geometrical parameters from CT. The number of independent variables is estimated based on the total number of samples. In this case, on one dependent variable there are three independent variables for 31 samples. Obtained formula for the logarithm of absolute permeability allows to determine the absolute permeability with correlation coefficient equal to $R=0.78$, while determination coefficient $R^{2}=0.61$. There is no strong dependence of the MLR absolute permeability from period, only one for lithology_-for sandstones. MLR absolute permeability correlates with PDP permeability for sandstones. Although, mudstones reduced the correlation, it is possible to 


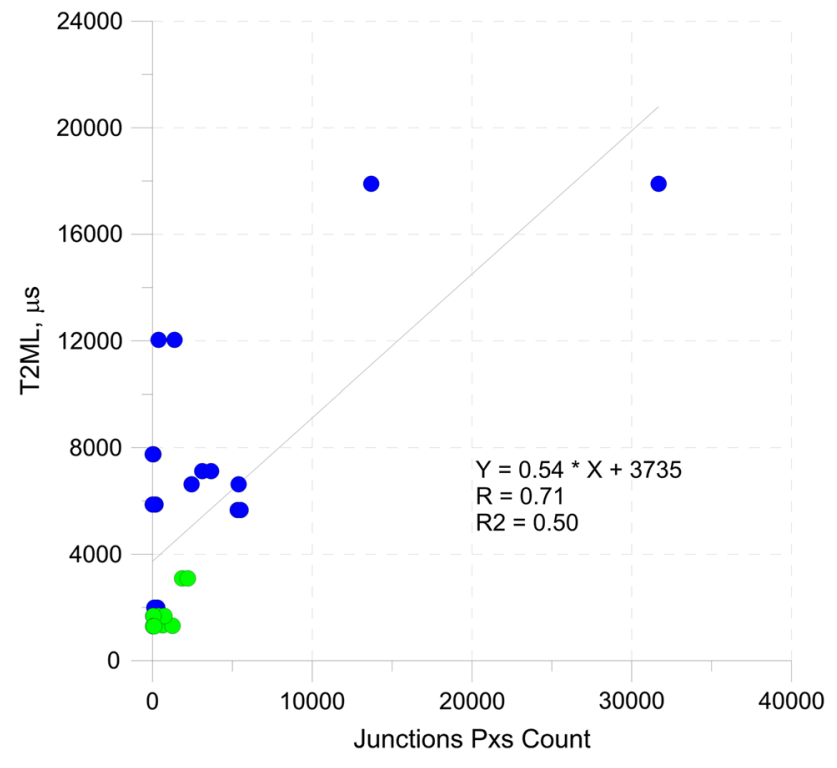

Fig. 9 Dependence of logarithmic $T 2$ mean (T2ML) from NMR on Junctions Pxs Count from CT. Colors: blue-sandstones, greenmudstones

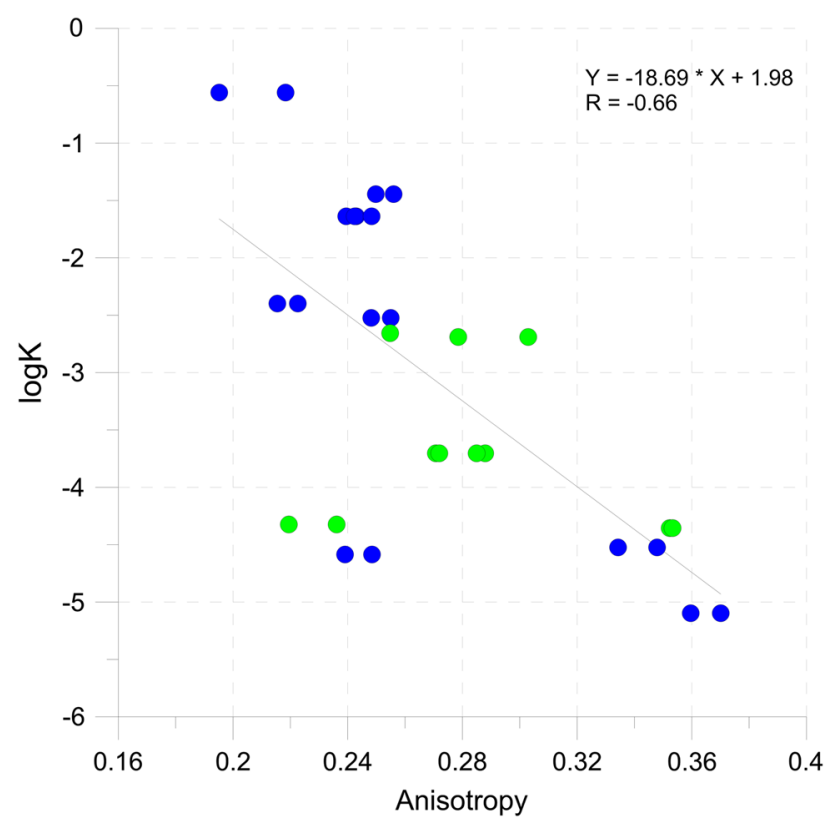

Fig. 10 Dependence of logarithm of absolute permeability from pulse- and pressure-decay method on anisotropy from CT. Colors as in Fig. 9

estimate the absolute permeability also for this group using the estimated formula.

The formula has the form of Eq. (1):

$$
\begin{aligned}
\log K= & -7.501+(-39.3116 * \text { Anisotropy }) \\
& +(13.6020 * \text { Feret Shape }) \\
& +(-5.0714 * \text { Feret Coefficient })
\end{aligned}
$$

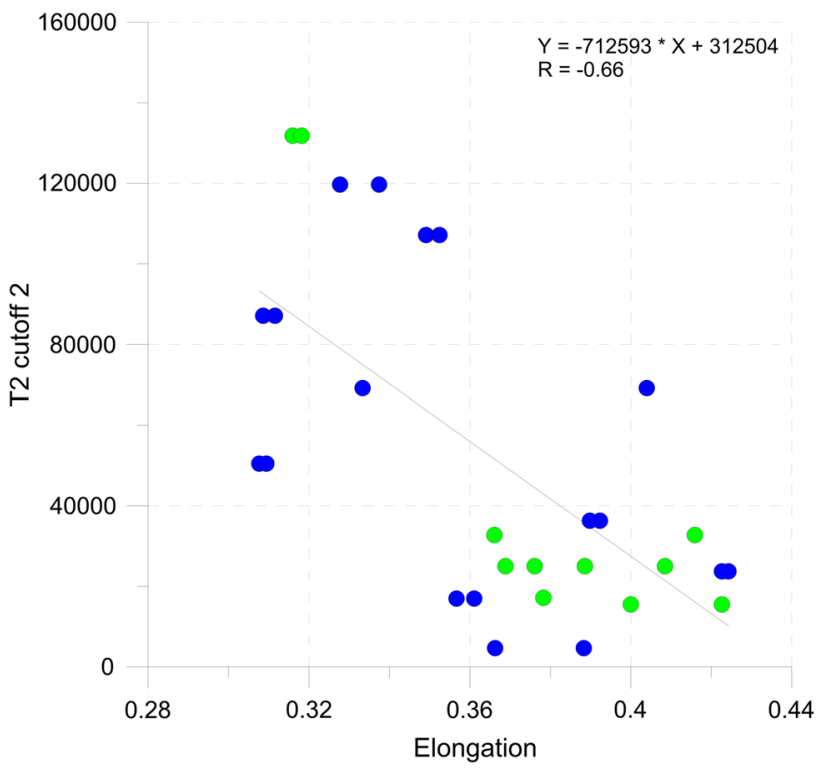

Fig. 11 Dependence of $T 2$ cutoff 2 (for bulk water irreducible and moveable fluid volume) from NMR on elongation from CT. Colors as in Fig. 9

Table 5 Multiple linear regression results for absolute permeability estimation

\begin{tabular}{lcc}
\hline Parameter & $\begin{array}{l}\text { Standardized partial regres- } \\
\text { sion coefficient }\end{array}$ & $\begin{array}{l}\text { Partial regres- } \\
\text { sion coefficient }\end{array}$ \\
\hline Intercept & & -7.0501 \\
Anisotropy & -1.3927 & -39.3116 \\
Feret shape & 0.9121 & 13.6020 \\
Feret coefficient & -0.4054 & -5.0714 \\
\hline
\end{tabular}

Table 5 presents the partial regression coefficient and the standardized one. Pore anisotropy has the largest influence on the absolute permeability, so the pores ability to fluid flow.

Figure 12 illustrates the comparison between the logarithm of absolute permeability form PDP $(\log K)$ and estimated based on MLR (log $K$ MLR).

\section{Conclusions}

X-ray nanotomography allowed for the complex parametrization of the pore space in the tight clastic rocks. Selected parameters connected with the geometrical features of pore space can be referred to the ability of fluid 


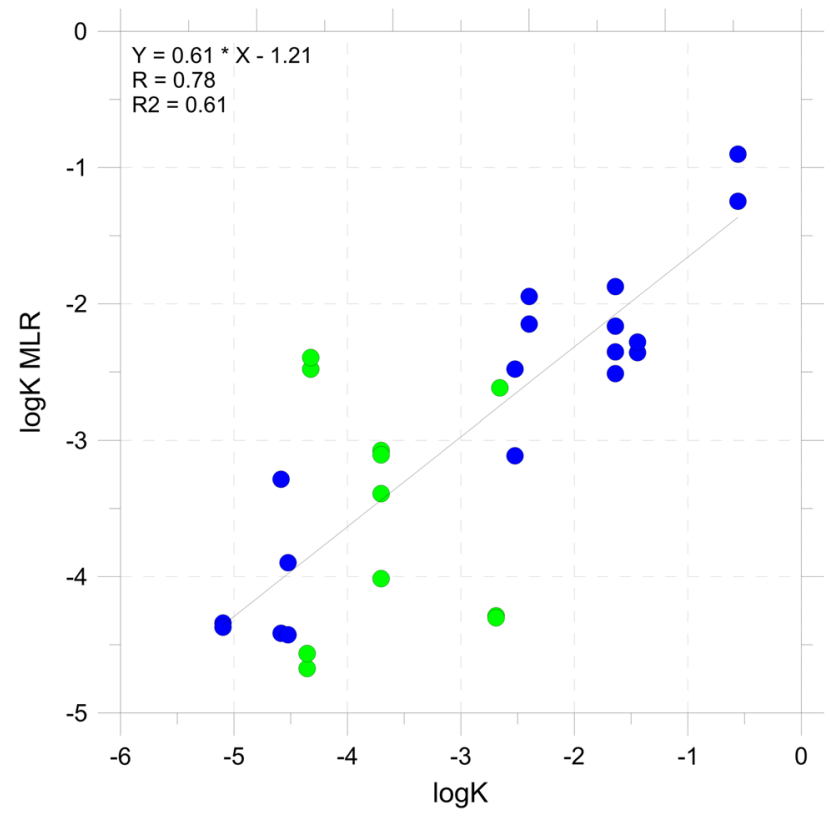

Fig. 12 Comparison of absolute permeability logarithm from PDP $(\log K)$ and estimated from MLR ( $\log K$ MLR). Colors as in Fig. 9

flow, as anisotropy, Feret shape or Feret coefficient. Shape factors, as Danielsson, Malinowska coefficient, 2nd circularity coefficient build relationships with the NMR spectroscopy parameters, which is related to the pore sizes. 3D skeleton analysis revealed the information about the pore structure, which in analyzed case is strongly influenced by the compaction and mineralogy. Pores are more elongated, angular, what definitely is not a benefit. Skeleton analysis provided the information about poor quality of the pore connections in the form of coordination number in both, sandstone and mudstone group. Dependence of logarithmic $T 2$ mean (T2ML) from NMR on Junctions Pxs Count from CT, as well as $T 2$ cutoff (for bulk water irreducible and moveable fluid volume) from NMR on elongation from CT, was observed for all the samples.

Using result from pulse- and pressure-decay permeability method, it was possible to estimate the equation for absolute permeability having only data from X-ray nanotomography image analysis. It is an advantage in the times of balance between costs of coring and laboratory measurements. Multiple linear regression was a key in determining the formula. Permeability in tight, gas-bearing clastic rocks is influenced by the anisotropy of pore shape and size. Presented equation can be used in the initial assessment of the reservoir potential of tight clastic rocks. Computed X-ray tomography together with other laboratory techniques, as nuclear magnetic resonance spectroscopy, is a valuable source of detailed parametrization of the pore space in rock samples.
Acknowledgements The paper was presented at the CAGG 2019 Conference "Challenges in Applied Geology and Geophysics" organized at the AGH University of Science and Technology, Krakow, Poland, September 10-13, 2019. Project was financed by the National Centre for Research and Development in Poland, program LIDER VI, Project no. LIDER/319/L-6/14/NCBR/2015: Innovative method of unconventional oil and gas reservoirs interpretation using computed X-ray tomography. Author thanks Polish Oil \& Gas Company and Orlen Upstream Co. for geological, laboratory and well logging data. Paper was financially supported by the Faculty of Geology Geophysics and Environmental Protection AGH UST funds in 2019 year.

Open Access This article is distributed under the terms of the Creative Commons Attribution 4.0 International License (http://creativeco mmons.org/licenses/by/4.0/), which permits unrestricted use, distribution, and reproduction in any medium, provided you give appropriate credit to the original author(s) and the source, provide a link to the Creative Commons license, and indicate if changes were made.

\section{References}

Al-Raoush R, Papadopoulos A (2010) Representative elementary volume analysis of porous media using X-ray computed tomography. Powder Technol 200:69-77

Caubit C, Hamon G, Sheppard A, Øren P (2009) Evaluation of the reliability of prediction of petrophysical data through imagery and pore network modelling. Petrophys 50:322-334

Cnudde V, Boone M (2013) High-resolution X-ray computed tomography in geosciences: a review of the current technology and applications. Earth Sci Rev 123:1-17

Cnudde V, Boone M, Dewanckele J, Dierick M, Van Hoorebeke L, Jacobs P (2011) 3D characterization of sandstone by means of $\mathrm{X}$-ray computed tomography. Geosphere 7:54-61

Feldkamp L, Davis L, Kress J (1984) Practical cone-beam algorithm. J Opt Soc Am 1:612-619

Ghanizadeh A, Clarkson ChR, Aquino S, Vahedian A (2017) Permeability standards for tight rocks: design, manufacture and validation. Fuel 197:121-137

Guo X, Shen Y, He S (2015) Quantitative pore characterization and the relationship between pore distributions and organic matter in shale based on Nano-CT image analysis: a case study for a lacustrine shale reservoir in the Triassic Chang 7 member, Ordos Basin, China. J Nat Gas Eng 27(3):1630-1640

Habrat M, Krakowska P, Puskarczyk E, Jędrychowski M, Madejski P (2017) The concept of a computer system for interpretation of tight rocks using X-ray computed tomography results. Studia Geotech et Mech 39(1):101-107

Handwerger D, Suarez-Rivera R, Vaughn K, Keller J (2011) Improved petrophysical core measurements on tight shale reservoirs using retort and crushed samples. In: SPE annual technical conference and exhibition, 30 October-2 November, Denver, Colorado, USA, SPE 147456, pp 1-19

Jarzyna J, Krakowska P, Puskarczyk E, Wawrzyniak-Guz K, Bielecki J, Tkocz K, Tarasiuk J, Wroński S, Dohnalik M (2016) X-ray computed microtomography - a useful tool for petrophysical properties determination. Comput Geosci 20(5):1155-1167

Jędrychowski M, Krakowska P, Puskarczyk E, Madejski P, Habrat M (2017) Segmentation method of pore space based on Fourier transform processing of micro-CT 3D data. In: 79th EAGE conference and exhibition 2017, 12-15 June, Paris, EarthDoc European Association of Geoscientists and Engineers database, https://doi. org/10.3997/2214-4609.201701266 
Josh M, Esteban L, Delle Piane C, Sarout J, Dewhurst DN, Clennell MB (2012) Laboratory characterization of shale properties. J Pet Sci Eng 88-89:107-124

Kaczmarek Ł, Wejrzanowski T, Skibiński J, Maksimczuk M, Krzyżak A (2017) High-resolution computed microtomography for the characterization of a diffusion tensor imaging phantom. Acta Geophys 65(1):259-268

Karpyn ZT, Alajmi A, Radaelli F, Halleck PM, Grader AS (2009) $\mathrm{X}$-ray CT and hydraulic evidence for a relationship between fracture conductivity and adjacent matrix porosity. Eng Geol 103(3-4):139-145

Kayser A, Knackstedt M, Ziauddin M (2006) A closer look at pore geometry. Oilfield Rev 18(1):4-13

Ketcham RA, Carlson WD (2001) Acquisition, optimization and interpretation of X-ray computed tomographic imagery: applications to the geosciences. Comput Geosci 27:381-400

Krakowska P (2017) Digital rock models of Precambrian and Paleozoic tight formations from Poland. Geol Q 61(4):896-907

Krakowska P, Puskarczyk E (2015) Tight reservoir properties derived by nuclear magnetic resonance, mercury porosimetry and computed microtomography laboratory techniques. Case study of Palaeozoic clastic rocks. Acta Geophys 63(3):789-814

Krakowska P, Dohnalik M, Jarzyna J, Wawrzyniak-Guz K (2016) Computed X-ray microtomography as the useful tool in petrophysics: a case study of tight carbonates Modryn formation from Poland. J Nat Gas Sci Eng 31:67-75

Krakowska P, Puskarczyk E, Jędrychowski M, Habrat M, Madejski P (2018) Innovative characterization of tight sandstones from Paleozoic basins in Poland using X-ray computed tomography supported by nuclear magnetic resonance and mercury porosimetry. J Pet Sci Eng 166:389-405

Liu T, Jin X, Wang M (2018) Critical resolution and sample size of digital rock analysis for unconventional reservoirs. Energies 11(1798):1-15
Madejski P, Krakowska P, Habrat M, Puskarczyk E, Jędrychowski M (2018) Comprehensive approach for porous materials analysis using a dedicated preprocessing tool for mass and heat transfer modeling. J Therm Sci 27(5):479-486

Mostaghimi P, Blunt MJ, Bijeljic B (2013) Computations of absolute permeability on micro-CT images. Math Geosci 45:103-125

Puskarczyk E, Krakowska P, Jędrychowski M, Habrat M, Madejski P (2018) A novel approach to the quantitative interpretation of rock parameters using nano-CT on the example of Paleozoic carbonates. Acta Geophys 66(6):1453-1461

Rabbani A, Ayatollahi S, Kharrat R, Dashti N (2016) Estimation of 3-D pore network coordination number of rocks from watershed segmentation of a single 2-D image. Adv Water Res 94:264-277

Ridgway K, Tarbuck K (1967) The random packing of spheres. Br Chem Eng 12:384-388

Stock SR (2008) Microcomputed tomography. Methodology and application. CRS Press, Boca Raton

Sun H, Yao J, Cao YC, Fan DY, Zhang L (2017) Characterization of gas transport behaviors in shale gas and tight gas reservoirs by digital rock analysis. Int J Heat Mass Transf 104:227-239

TIBCO Software (2017) Statistica help. On-line version

Verri I, Della Torre A, Montenegro G, Onorati A, Duca S, Mora CA, Radaelli F, Trombin G (2017) Development of a digital rock physics workflow for the analysis of sandstones and tight rocks. J Pet Sci Eng 156:790-800

Wellington SL, Vinegar H (1987) X-ray computerized tomography. J Pet Technol 39:885-898

Zhang L, Lu S, Xiao D, Li B (2017) Pore structure characteristics of tight sandstones in the northern Songliao Basin, China. Marine Pet Geol 88:170-180 